\title{
Pengaruh Usia Menarche terhadap Tinggi Badan Wanita di Daerah Endemis Gondok
}

\author{
Muhammad Taufiq Hidayat $^{1}$, Selfi Handayani ${ }^{2}$, Siti Munawaroh ${ }^{2}$ \\ 1.Program Studi Kedokteran Universitas Sebelas Maret \\ 2.Bagian Anatomi Fakultas kedokteran Universitas Sebelas Maret
}

Korespondensi : munafkuns@gmail.com

\begin{abstract}
ABSTRAK
Pendahuluan: Tinggi badan seseorang dipengaruhi oleh berbagai macam faktor. Salah satu hal yang memengaruhi tinggi badan akhir seorang perempuan adalah usia mendapatkan menarche. Pada saat menarche terjadi, maka hormon seksual pada tubuh wanita akan mulai aktif dan akan merangsang penutupan lempeng epifisis sehingga mengakibatkan tinggi badan akhir pada wanita yang mengalami usia menarche lebih terlambat akan lebih tinggi dibandingkan dengan yang mengalami usia menarche lebih dini. Perempuan yang tinggal di daerah endemis gondok terutama yang tinggal di wilayah pegunungan sering terjadi gangguan akibat kekurangan iodium. Akibatnyasering mengalami usia menarche yang lebih dini dibandingkan dengan perempuan di daerah yang tidak endemis gondok. Penelitian ini bertujuan untuk menganalisis hubungan antara usia menarche dan tinggi badan pada daerah endemis gondok.

Metode: Penelitian ini bersifat observasional yang dilakukan di daerah endemis gondok yaitu Ngargoyoso Karanganyar. Sampel berusia diatas 20 tahun yang dengan postur tegak yang dipilih dengan sampling acak sederhana. Pengumpulan data dilakukan dengan pengukuran tinggi badan menggunakan statometer dan pengisian data usia menarche. Data dianalisis dengan uji korelasi Pearson $(\alpha=0,05)$ yang sebelumnya sudah dilakukan uji normalitas dengan uji Kolmogorov Smirnov.

Hasil: Rerata usia menarche sampel adalah 13,38 tahun dengan nilai terendah usia 11 tahun dan yang tertinggi usia 18 tahun. Sedangkan rerata tinggi badan sampel adalah $156,8 \mathrm{~cm}$ dengan nilai terendah $139 \mathrm{~cm}$ dan tertinggi $168 \mathrm{~cm}$. Dari hasil uji korelasi Pearson didapatkan bahwa tinggi badan secara signifikan berhubungan dengan usia menarche seorang wanita di daerah endemis gondok $(\mathrm{p}=0,001)$.

Kesimpulan: Usia menarche berhubungan dengan tinggi badan di daerah endemis gondok. Semakin dini usia menarche maka akan semakin pendek tinggi badan akhir seorang wanita dan berlaku pula sebaliknya.
\end{abstract}

Kata Kunci: menarche, tinggi pada wanita, tinggi badan, gondok, hipotiroid

\begin{abstract}
Introduction: Height affected by various factor. One factor that can affect female's height is menarcheal age. Sexual hormone in female's body will be activated at menarche and it will stimulate the closure of epiphyseal plate. Final height in female with late menarche is higher than female with early menarche. While in goiter endemic areas with Iodine Deficiency Disorder especially in mountain area, it has earlier menarcheal age than normal female that live in non goiter endemic area. This study aimed to analyze the relationship between age at menarche and height endemic goiter.

Methods: This study was an observational study with cross-sectional design. It was held in the goiter endemic Ngargoyoso, Karanganyar. Samples of women aged over 20 years with upright posture that live in Ngargoyoso were obtained by simple random sampling, then measuring the height using statometer and obtaining menarcheal age by questioner.
\end{abstract}


Data were analyzed using Pearson correlation test $(\alpha=0.05)$, which had previously been tested for normality by Kolmogorov Smirnov.

Results: The mean age of menarche sample was 13.38 years with the lowest age of 11 years and the highest age of 18 years. While the average height was $156.8 \mathrm{~cm}$ samples with the lowest height was $139 \mathrm{~cm}$ and the highest was $168 \mathrm{~cm}$. Pearson correlation test results showed that height was significantly associated with age at menarche woman endemic goiter $(p=0.001)$.

Conclusions: Age of menarche associated with height in an endemic goiter area. The earlier age of menarche will affect the final height of the woman.

Keywords: Menarche, Height in women, Height, Goiter, Hypothyroid

\section{PENDAHULUAN}

Masa remaja merupakan tahapan antara masa kanak kanak menuju masa dewasa yang terjadi pada usia 10-19 tahun ${ }^{1}$. Sebelum memasuki masa remaja, seseorang akan melewati suatu periode yang disebut pubertas. Pubertas merupakan suatu periode transisi dari anak anak menjadi dewasa yang mengakibatkan perubahan fisiologis, somatik dan berkaitan dengan perkembangan organ genitalia interna dan externa serta karakteristik seks sekunder ${ }^{2,3}$. Pubertas pada seorang wanita merupakan tanda dari mulai berfungsinya organ reproduksi yang dia miliki. Hal ini ditandai dengan keluarnya darah menstruasi untuk pertama kalinya, atau disebut menarche ${ }^{4}$.

Beberapa tahun belakangan ini telah terjadi penurunan usia menarche menjadi usia yang lebih muda. Selama beberapa decade, penurunan usia menarche menunjukkan penurunan yang signifikan sebanyak 4 tahun lebih muda untuk mendapat menarche dalam 150 tahun belakangan ${ }^{5}$. Penurunan usia menarche berhubungan dengan faktor biologis yaitu genetik dan faktor lingkungan seperti ekonomi, gizi, keadaan keluarga, tempat tinggal. kegiatan fisik dan pemaparan psikis ${ }^{6}$.

Percepatan maupun perlambatan usia menarche mempunyai konsekuensi yang berkaitan dengan aspek biologis dan lingkungan. Salah satu konsekuensi dari gangguan usia menarche dapat dilihat dari faktor antropometri seperti tinggi badan. Hal ini terjadi karena pada orang yang menarche lebih dini akan merangsang penutupan lempeng epifisis dimana ini terjadi akibat rangsangan steroid hormon ${ }^{7}$.

Salah satu perubahan status hormonal pada wanita yang telah mengalami menstruasi adalah meningkatnya kadar FSH yang akan merangsang pertumbuhan folikel yang nantinya akan menghasilkan estrogen, sehingga pada wanita yang telah mengalami menarche atau mengalami early menarche akan lebih tinggi kadar estrogen nya ${ }^{8-9}$. Estrogen sebagai steroid hormon inilah yang akan merangsang penutupan dari cakram epifisis $^{10}$.

Tinggi badan seseorang dipengaruhi oleh pertumbuhan dari tulang panjangnya akibat dari proses osifikasi endokondral dimana didahului oleh proses chondrogenesis sehingga terbentuk kartilago hialin. Proses ini kemudian akan disebut pusat osifikasi primer di daerah shaft bone atau diafisis dan dilanjutkan pusat osifikasi sekunder di daerah lempeng epifisis pada orang dewasa ${ }^{11-12}$. Pada pubertas, meningkatnya kadar estrogen akan memengaruhi apoptosis dari kondrosit dan diikuti kalsifikasi pada lempeng epifisis sehingga pertumbuhan akan berhenti ketika seluruh lempeng epifisis digantikan oleh tulang dan hanya menyisakan garis epifisis yang akan menghilang ketika dewasa. Pubertas pada wanita yang akan merangsang penutupan lempeng epifisis ini akan sangat dipengaruhi oleh usia menarche dari wanita tersebut ${ }^{13}$. 
Hubungan hormon tiroid terhadap tinggi badan secara linear sendiri terjadi melalui efek stimulasi terhadap sintesis DNA pada osteoblas dan sel lain. Akibatnya, tingginya kadar hormon tiroid seperti pada kondisi hipertiroid akan berbanding lurus dengan tinggi badan akhir seseorang. Sebaliknya, rendahnya kadar hormon tiroid pada kondisi hipotiroid akan mengakibatkan rendahnya tinggi badan akhir seseorang ${ }^{14}$.

Penelitian mengenai usia menarche dan tinggi badan pernah dilakukan di 9 negara Eropa pada tahun 2007. Penelitian serupa juga pernah dilakukan penelitian pada mahasiswi Universitas Sumatra Utara $^{15-17}$. Namun demikian, belum pernah dilakukan penelitian tentang korelasi antara usia menarche dan tinggi badan di daerah endemis gondok. Tujuan penelitian ini adalah untuk menganalisis korelasi antara usia menarche dengan tinggi badan di daerah endemis gondok.

\section{METODE}

Penelitian ini merupakan penelitian observasional analitik dengan pendekatan cross-sectional. Lokasi Penelitian adalah pada daerah Kecamatan Ngargoyoso Kabupaten Karanganyar, Provinsi Jawa Tengah yang merupakan daerah endemis gondok ${ }^{18}$. Populasi penelitian ini adalah wanita berusia $\geq$ 20 tahun yang diambil dengan random sampling.

Metode analisis data menggunakan uji uji korelasi Pearson.

Etichal clearance dikeluarkan oleh Komisi Etik Penelitian Kesehatan Dr. Moewardi Surakarta dengan No. 719 / IX / HREC / 2016

\section{HASIL}

Penelitian ini melibatkan 71 wanita di Ngargoyoso. Adapun karakteristik responden dapat dilihat di Tabel 1.
Tabel 1. Karakteristik responden penelitian.

\begin{tabular}{ccccc}
\hline & Rerata & Median & Minimal & Maksimal \\
\hline Umur & 39.07 & 39 & 20 & 70 \\
$\begin{array}{c}\text { Usia } \\
\text { Menarche } \\
\text { Tinggi } \\
\text { Badan }\end{array}$ & 13,38 & 13 & 11 & 18 \\
\hline
\end{tabular}

Hasil pengukuran tinggi badan setiap kelompok usia menarche dapat dilihat pada Tabel 2.

Tabel 2. Data usia menarche dan tinggi badan

\begin{tabular}{|c|c|c|c|c|c|c|c|c|}
\hline Tinggi & \multicolumn{7}{|c|}{ Usia Menarche } \\
\cline { 2 - 5 } $\begin{array}{c}\text { Badan } \\
(\mathrm{cm})\end{array}$ & 11 & 12 & 13 & 14 & 15 & 16 & 17 & 18 \\
\hline $\begin{array}{c}130- \\
139\end{array}$ & 1 & 1 & 0 & 0 & 0 & 0 & 0 & 0 \\
\hline $\begin{array}{c}140- \\
149\end{array}$ & 2 & 18 & 6 & 1 & 0 & 0 & 0 & 0 \\
\hline $\begin{array}{c}150- \\
159\end{array}$ & 0 & 3 & 9 & 10 & 9 & 2 & 1 & 1 \\
\hline $\begin{array}{c}160- \\
169\end{array}$ & 0 & 0 & 0 & 2 & 3 & 1 & 0 & 1 \\
\hline
\end{tabular}

Hasil uji Pearson didapatkan nilai $\mathrm{p}=$ 0,001 dan $r=0,702$. Artinya terdapat pengaruh yang signifikan antara usia menarche dan tinggi badan dengan tingkat korelasi yang positif kuat. Maknanya semakin dini seorang wanita mengalami usia menarche maka semakin rendah tinggi badan akhir wanita tersebut. Demikian pula sebaliknya.

\section{PEMBAHASAN}

Hasil penelitian menunjukkan adanya hubungan yang signifikan antara usia menarche dan tinggi badan wanita di daerah endemis gondok, dengan tingkat korelasi yang kuat. Korelasi usia menarche dan tinggi badan ini pernah dilakukan oleh Orland-Moret et al (2005), Gharravi et al (2008) serta Amina (2008) yang menyatakan adanya hubungan antara tinggi badan seorang wanita dengan usia menarche adalah berhubungan secara signifikan. Akan tetapi tingkat korelasi dari masing-masing penelitian tersebut berbedabeda $^{15,-17}$. 
Koefisien korelasi dari penelitian ini $\mathrm{r}=0.702$ yang menunjukkan hubungan yang kuat. Tingkat korelasi yang serupa juga didapatkan pada penelitian Gharravi et al (2008), yaitu sebesar $r=0.893$. Hasil yang berbeda didapatkan dalam penelitian OrlandMoret et al (2005), yaitu $\mathrm{r}=0,31^{14,16}$.

Hasil ini terjadi karena menarche akan memengaruhi kadar estrogen tubuh yang nantinya akan memengaruhi tinggi badan melalui apoptosis dari kondrosit dan diikuti kalsifikasi pada lempeng epifisis sehingga pertumbuhan akan berhenti ketika seluruh lempeng epifisis digantikan oleh tulang dan hanya menyisakan garis epifisis yang akan menghilang ketika dewasa. Selain itu menarche pada wanita juga diikuti dengan peningkatan kadar growth hormon yang akan merangsang proliferasi cepat sel sel. Pada wanita yang sudah menarche dengan yang belum akan terjadi perbedaan kadar GH lebih tinggi hingga beberapa kali lipat pada wanita yang sudah menarche. Tinggi nya kadar GH ini akan merangsang pertumbuhan tinggi badan lebih cepat pada wanita yang belum mengalami menstruasi. Pertumbuhan ini akan terus berlangsung hingga lempeng epifisis menutup, sehingga tinggi badan akhir tetap akan lebih tinggi pada wanita yang mengalami menstruasi lebih lambat ${ }^{6,13}$.

Hal ini berarti semakin tua umur seorang wanita untuk mendapatkan menarche akan semakin tinggi hasil pengukuran tinggi badan akhir wanita tersebut.

Karakteristik tempat yang dijadikan penelitian oleh peneliti kali ini adalah di daerah endemis gondok yaitu Ngargoyoso Karanganyar. Pada kondisi gondok hipotiroid maka akan terjadi penurunan rangsangan melalui jalur hipotalamus dan hipofisis sehingga akan terjadi penurunan kadar GH. GH sendiri akan memengaruhi osifikasi endokondral pada lempeng hipofisis, sehingga penurunan GH pada hipotiroid akan menurunkan tinggi badan rata rata ${ }^{19}$.
Selain itu, terdapat hubungan langsung antara hormon tiroid dengan pertumbuhan dan perkembangan tubuh tanpa melalui jalur GH. Hormon tiroid memengaruhi pertumbuhan melalui beberapa mekanisme. Pengaruh hormon thyroid dengan pertumbuhan pertama kali di observasi pada metamorfosis hewan amfibi. Selama proses perkembangan, apoptosis dan proliferasi dari sel dipengaruhi oleh hormon triiodotironin (T3). Studi pada hewan uji menunjukkan bahwa hormon tiroid merangsang proliferasi mitogen dari sel sel hepatosit. Selain itu juga hormon tiroid berpengaruh terhadap penyembuhan luka dan proliferasi dari sel dan terdapat indikasi hormon tiroid juga berpengaruh terhadap morfogenesis dan diferensiasi dari jaringan epitelial dan mesenkimal paru paru ${ }^{20-23}$. Hubungan hormon tiroid terhadap tinggi badan secara linear sendiri melalui efek stimulasi terhadap sintesis DNA pada osteoblas dan sel lain ${ }^{13}$. Hal ini mendukung karakteristik sampel yang peneliti temukan, yaitu tinggi badan sampel tidak begitu tinggi, dengan rata rata tinggi badan 150,67 dengan tinggi badan minimal $139 \mathrm{~cm}$ dan tinggi badan tertinggi $168 \mathrm{~cm}$. Sebanyak 49 sampel dari 71 sampel memiliki tinggi badan dibawah $155 \mathrm{~cm}$ sedangkan tinggi badan rata rata wanita Indonesia menurut Badan Pusat Statistik Indonesia berkisar antara 155-165 $\mathrm{cm}^{24}$. Akan tetapi, walaupun terjadi penurunan tinggi badan rata rata daripada daerah yang tidak mengalami hipotiroid, ternyata usia menarche tetap berkaitan dengan tinggi badan akhir dari seorang wanita. Sampel yang memiliki usia menarche yang lebih muda akan memiliki tinggi badan akhir yang lebih rendah daripada sampel dengan usia menarche yang lebih tua, sehingga hubungan antara usia menarche dan tinggi badan ternyata tidak begitu terpengaruh oleh kondisi lingkungannya endemis gondok.Pembahasan berisi diskusi yang menghubungkan dan membandingkan hasil penelitian dengan teori yang diuji dan hasil-hasil penelitian 
sebelumnya. Pembahasan dapat diakhiri dengan menyebutkan keterbatasan penelitian dan saran untuk penelitian lebih lanjut.

\section{KESIMPULAN}

Terdapat hubungan yang siginifikan antara usia menarche dan tinggi badan di daerah endemis gondok dengan tingkat korelasi kuat.

\section{UCAPAN TERIMA KASIH}

Ucapan terima kasih kami sampaikan kepada seluruh responden dan pihak yang sudah membantu penelitian ini.

\section{DAFTAR PUSTAKA}

1. WHO (2011). Adolescence An Age of Opportunity.

www.who.int/maternal_child_adolescent/topi cs/adolescence/dev/en - (Diakses Juni 2016)

2. Sherwood, Lauralee (2011). Fisiologi Manusia. Jakarta: EGC

3. Yusuf, Syamsu (2011). Psikologi perkembangan anak dan remaja. Bandung: PT Remaja Rosdakarya

4. Pacarada M, Lulaj S, Kongjeli G, Obertinca B. Impact of socioeconomic Factor on onset of menarche in Kosovar Girls. BMJ. Available

from:http://www.cjmed.net/journal/articleinfo /id/291?PHPSESSID=472024dcc8dda cb7185cf1a8157560a2 2

5. Ahmed SM, Waheed MA, Ahmad F, Danish SH (2014). Factors contributing to early menarche in school girls. Journal of Pakistan Medical Ascociation. Pp: 1

6. Kin-Chuen Leung, Gudmundur Johannsson, Gary M. Leong, Ken K. Y. Ho (2011). Estrogen Regulation of Growth Hormone Action. Endrocrine Rev. 2011; 20:4

7. Vanderschueren D, Laurent MR, Claessens F, Gielen E, Lagerquist MK, Vandenput L, et al (2014). Sex steroid actions in male bone. Endocr Rev. 2014;35:906-960

8. Apter D, Vihko, R (1985). Premenarcheal endocrine changes in relation to age at menarche. Clin Endocrinol. Jun;22(6):753-60.

9. De K (2016). Physical Growth and Relation of Menarche with Anthropometry.
Anthropology. 4:4. DOI: 10.4172/23320915.1000172

10. Leeson, C. Roland, et al (1996). Buku ajar histologi . Jakarta : EGC

11. Muthmainnah,Suyatmi,Listyaningsih E, Ayusari AA, Afifah ZN (2014). Buku Pedoman Praktikum Histologi Semester III. Fakultas Kedokteran Sebelas Maret : Surakarta

12. Shim, Kye Shik (2015). Pubertal growth and epiphyseal fusion. Pediatr Endocrinol Metab. 20(1): 8-12.

13. Zhong M, Carney DH, Boyan BD, Schwartz Z (2011). 17ß-Estradiol regulates rat growth plate chondrocyte apoptosis through a mitochondrial pathway not involving nitric oxide or MAPKs.. Endocrinology 152 (1): 82-92.

14. Omer Tarim (2011). Thyroid hormone and growth in health and disease. J Clin Res Pediatr Endocrinol. 2011 Jun; 3(2): 51-55.

15. Onland-Moret N.C, Peeters P.H, Van Gils C.H, F. Clavel-Chapelon, T. Key, A. Tjønneland, A. Trichopoulou, R. Kaaks, J. Manjer, et al (2005). Age at Menarche in Relation to Adult Height The EPIC Study. Am. J. Epidemiol. (1 October 2005) 162 (7): 623

632.doi: 10.1093/aje/kwi260

16. Nur Amina Binti Abdul Muin (2008). Hubungan antara usia menarche dan tinggi badan mahasiswi angkatan 2008 di Fakultas Kedokteran Universitas Sumatara Utara. Skripsi.

17. Gharravi AM, Gharravi S, Marjani A, Moradi A, Golalipour (2008). Correlation of age at menarche and height in Iranian student girls living in Gorgan -Northeast of Iran. Journal of Pakistan Medical Ascossiation. Aug, 2008:421

18. Dinas Kesehatan Karanganyar (2012). eprints.ums.ac.id/32135/5/BAB\%20I.pdf Diakses Juni 2016

19. Smyczynska J, Hilczer M, Stawerska R, Lewinskicorresponding A (2010). Thyroid function in children with growth hormone (GH) deficiency during the initial phase of GH replacement therapy - clinical implications. Thyroid Res. 2010; 3: 2.

20. Tarim $O$ (2007). Abnormal endocrine test results due ton on-endocrine condirtions. In: Lifshitz

F,editor. PediatricEndocrinology. London: Informa Health Care; 2007. pp. 581-595. 
21. Tata JR. Amphibian metamorphosis as a model for the developmental actions of thyroid hormones. Mol Cell Endocrinol. 2006;246:10-20.

22. Safer JD, Crawford TM, Holick MF (2005). Topical thyroid hormone accelerates wound healing in mice. Endocrinology. 2005;146:4425-4430

23. Malik R, Mellor N, Selden C, Hodgson H (2003). Triiodothyronine enhances the regenerative capacity of the liver following partial hepatectomy. Hepatology. 2003;37:79-86

24. Indonesia Family Life Survey (1997). Repositories.cdlib.org. 2003-0401.Retrieved 2016-06-22. 